\title{
The role of preservice teachers' implicit attitudes and causal attributions: a deeper look into students' ethnicity
}

\author{
Sabine Glock ${ }^{1}$ D $\cdot$ Hannah Kleen ${ }^{1}$
}

Accepted: 13 June 2021

(C) The Author(s) 2021

\begin{abstract}
Previous research has provided evidence that teachers implicitly hold more negative attitudes toward ethnic minority students than toward ethnic majority students. Furthermore, they attribute the lower educational success of ethnic minority students predominantly to internal causes. So far, it is not known how implicit attitudes and causal attributions are related to preservice teachers' judgments of students' academic competencies. We conducted a study to close this research gap. In a sample of preservice teachers, our study showed mainly negative implicit attitudes toward ethnic minority students. On general, the preservice teachers made external attributions. Implicit attitudes as well as causal attributions predicted the judgments. Preservice teachers with more negative attitudes and preservice teachers, who attributed the failure of ethnic minority students to these students' abilities, less favorably judged the competence of ethnic minority students. Our results highlight the role of teachers' attitudes and causal attributions in determining the disadvantages that ethnic minority students experience in school.
\end{abstract}

Keywords Ethnic minority students $\cdot$ Implicit attitudes · Teacher judgment $\cdot$ Teachers' causal attributions

Ethnic minority students often perform worse in school than their ethnic majority peers (Jordan, 2010). When investigating the reasons for ethnic minority students' low academic achievement, one strand of research has focused on the contribution of teachers. In this regard, research has shown that teachers expect less from ethnic minority students than they do from ethnic majority students (Tobisch \& Dresel, 2017); as a result, teachers (Glock, 2016; Tobisch \& Dresel, 2017; Kleen \& Glock, 2018a) and preservice teachers judge ethnic minority students less favorably than ethnic majority students (Bonefeld \& Dickhäuser, 2018). These disadvantages in teacher judgments have appeared despite the fact that experimental studies in this field held constant all information except for students' ethnic background. Such judgments are assumed to be influenced by teachers' attitudes, particularly by their implicit attitudes, and research has supported this assumption (van den Bergh et al., 2010; Peterson et al., 2016; Glock \& Böhmer, 2018). Studies have also shown that implicit attitudes are related to causal attributions (Teachman et al.,

Sabine Glock

glock@uni-wuppertal.de

1 Teacher and Teaching Quality, Leibniz Institute for Research and Information in Education, Rostocker Straße 6, D-60323 Frankfurt am Main, Germany
2003) and, in turn, that causal attributions are related to judgments (Glock \& Schuchart, 2020). To our knowledge, no research in the educational context involving ethnic minority students has combined teachers' implicit attitudes, causal attributions for the low educational success of ethnic minority students, and academic competency judgments. We aimed to close this research gap by investigating these variables and their relations in a sample of preservice teachers.

\section{Attitudes}

Attitudes are defined as positive, negative, or neutral evaluations of an entity such as a member of a social group (Eagly \& Chaiken, 1993). People's attitudes are formed through direct interpersonal contact and indirect experiences (e.g., through parents or media reports) with members of different social groups (Eagly \& Chaiken, 1993). Thus, socialization, culture, and contact influence people's attitudes toward social groups (Hamilton \& Sherman, 1996). Attitudes are stored as mental representations in associative networks, whereby they represent links between the entity and the corresponding evaluation (Smith, 1998).

We differentiate between implicit and explicit attitudes (Gawronski \& Bodenhausen, 2006). Explicit attitudes are the controlled evaluations that are conscious and activated 
through complex cognitive processes (Gawronski \& Bodenhausen, 2006). Implicit attitudes are automatic evaluations that are subject to unconscious, associative mental processes (Gawronski \& Bodenhausen, 2006). It is often assumed that implicit and explicit attitudes influence behaviors and judgments differently (Gawronski \& Bodenhausen, 2006). Controlled, conscious behaviors and judgments should mainly rely on explicit attitudes, whereas more automatic behaviors are assumed to be strongly guided by implicit attitudes (Olson \& Fazio, 2009a). However, the two processes are not distinct (Olson \& Fazio, 2009a). Implicit attitudes are likely to also influence controlled processes because of their automatic nature (Olson \& Fazio, 2009b). Furthermore, explicit attitudes might influence automatic processes, for example, in important situations that prompt a lot of motivation (Olson \& Fazio, 2009b).

In the educational context, research has shown that preservice (Glock et al., 2013; Glock \& Karbach, 2015; Bonefeld \& Dickhäuser, 2018) and inservice teachers (Kleen \& Glock, 2018b) held more negative implicit attitudes toward ethnic minority than toward ethnic majority students. More specifically, inservice teachers' implicit attitudes were more negative than those of preservice teachers, but both groups held negative implicit attitudes. However, one recent review (Denessen et al., 2021) and a meta-analysis (Pit-ten Cate \& Glock, 2019) did not find differences between preservice and inservice teachers but generally reported negative implicit attitudes. This does not seem to stem entirely from a strong negative evaluation of ethnic minority students but mainly results from more positive implicit attitudes toward ethnic majority students (Glock \& Karbach, 2015). Teachers' and preservice teachers' explicit attitudes toward ethnic minority students have mostly been positive (van den Bergh et al., 2010; Kleen \& Glock, 2018c). Notwithstanding these different measures, implicit and explicit attitudes play a role in explaining teachers' different judgments and behaviors.

\section{Causal Attributions}

Teachers' and preservice teachers' judgments are often in favor of ethnic majority students and thereby tend to disfavor ethnic minority students (Tobisch \& Dresel, 2017; Bonefeld \& Dickhäuser, 2018; Kleen \& Glock, 2018a) even though judgments about ethnic minority students have been found to be more accurate than those about ethnic majority students (Tobisch \& Dresel, 2017). Therefore, stereotypical beliefs do not always come into play when teachers judge ethnic minority students. However, stereotypical beliefs inform people about the traits and behaviors that members of a social group may show (Smith, 1998). Furthermore, people search for causes of others' behaviors (Weiner, 2000). When people try to explain the behavior of others, they often engage in the fundamental attribution error, which specifies that people consistently overlook situational constraints and instead emphasize dispositions (Ross, 1977). The ultimate attribution error extends this concept to stereotyped groups (Pettigrew, 1979) such that people attribute the negative behavior of a group member to stable dispositions, and this tendency is enhanced for ethnic minority groups (Pettigrew, 1979). When connected to Weiner's (1985) attribution theory, people attribute the negative behavior of stereotyped groups mainly to internal causes. These are located in the person and can be either stable or variable. Stable internal causes are attributions to the person's ability, intelligence, or personality (Hewstone, 1990) and are thus uncontrollable, whereas variable internal causes refer to causes that are also in the person but are under individual control, such as effort (Weiner, 1985). Intelligence can be seen as a facet of ability and competence (Cuddy et al., 2008), whereby subject-related ability is often more highly correlated with academic achievement than general intelligence (Heyder et al., 2017). However, both add to internal stable causes. When it comes to personal behavior, the situational constraints refer to external causes that can be either controllable or not (Weiner, 1985). Research has shown that teachers primarily attribute their students' educational failures to internal causes (Wang \& Hall, 2018), whereas they are likely to take credit for their students' successes (Yehuda, 2002). They predominantly attribute high-achieving students' successes to internal causes (Natale et al., 2009), just as they do for the failures of low-achieving students (Tur-Kaspa \& Weisel, 2004).

When taking into account ethnic or racial background, research has shown that teachers attributed the performance of African American students to external causes such as luck or the easiness of the tasks (Wiley \& Eskilson, 1978). In general, preservice teachers with more negative stereotypes attributed ethnic minority students' educational failures mainly to internal causes (Froehlich et al., 2016). Teachers did the same to explain ethnic minority students' problems (Jackson, 2002). Teachers attributed ethnic majority students' successes to internal causes (Tom \& Cooper, 1986) but attributed ethnic minority students' successes to external causes (Riley \& Ungerleider, 2012) or effort (Wissink \& de Haan, 2013).

\section{Two-Stage Model of Dispositional Attributions}

Taken together, not only their implicit attitudes but also their causal attributions might predict preservice teachers' judgments of ethnic minority students' competencies in different educational domains. According to the two-stage model of dispositional attributions (Trope, 
1986), people derive trait judgments on the basis of two processes. A first associative and automatic process - identification - relies on situational, behavioral, and identity cues (Trope, 1986, 2004). Identity cues refer to prior information about the person, such as group membership (Gawronski \& Creighton, 2013), which informs people about the stereotypical attributes this person might possess. This should activate implicit attitudes, as these are activated by the presence of people belonging to social groups (Fazio, 2001). The meaning of the stereotypical trait attributes are also positively related to attitudes (Fishbein, 2008), and thus, implicit attitudes have been shown to predict trait judgments (Lambert et al., 2005).

At the second stage, the categorization of the situation, the behavior, and the identity of the person is relevant (Trope, 1986). Hence, the two stages are assumed to occur outside conscious awareness to some extent (Trope \& Gaunt, 1999) and to add subsequent processes to the trait judgment (Gawronski \& Creighton, 2013). These three kinds of information have a different impact on trait judgments (Trope, 1986). Whereas behavioral and identity information will positively impact the strength of trait judgments, situational cues will lessen the strength (Trope, 1986). As outlined above, people relate identity information to group membership (Gawronski \& Creighton, 2013), which can trigger implicit attitudes toward this group (Gonsalkorale et al., 2010). Behavioral information can be assumed to refer to internal attributions as people spontaneously make inferences from behavior to internal stable causes (e.g., dispositions), internal variable causes, and other attributes (Uleman et al., 1996). The situational cues in the two-stage model might reflect external attributions, as situational constraints and behavior in certain contexts are taken into account (Trope, 1986).

\section{Hypotheses}

Corresponding to the theoretical framework, we expected that identity, behavioral, and situational information would predict academic competency judgments about students. This information was operationalized using implicit attitudes and internal and external attributions. More specifically, we expected that more positive implicit attitudes would result in higher competency judgments. As we asked about the attributions of ethnic minority students' lower educational success, we also expected that lower internal and higher external attributions would result in higher competency judgments. In Germany, one of the most disadvantaged (Kristen, 2000) and largest group of ethnic minority students are students with Turkish roots (Destatis, 2017). Therefore, we operationalized students' ethnic minority background by referring to Turkish-origin students.

\section{Method}

\section{Participants}

A total of 167 preservice teachers participated in this study (114 female, 50 male, 3 did not indicate their gender; Age: $M$ $=24.87$ years, $S D=2.77$ ), and 29 preservice teachers have an ethnic minority background themselves (11 had Turkish roots).

\section{Materials}

\section{Implicit Attitudes}

We employed an Implicit Association Test (IAT; Greenwald et al., 1998), because the IAT is the method, about which we know most in terms of validity and reliability (Nosek et al., 2005). We contrasted seven male names indicating students with Turkish roots (e.g., Yusuf, Caner, Oktay) with seven male names indicating a native German background (e.g., Lukas, Finn, Jonas). We used 20 pleasant (e.g., happy, warm) and 20 unpleasant words (e.g., evil, sneaky) as attribute categories. As this was the first study connecting attitudes, causal attributions, and judgments, we decided to use solely male names, in order to avoid a possible confound with students' gender. As a proxy for the internal consistency, we used the correlation between the IAT scores resulting from the test trials and those resulting from the practice trials, as this is the suggested procedure for analyzing the internal consistency according to Greenwald et al. (2003). This correlation was $r$ $=.67$. To calculate the $D$-measure, we used the improved scoring algorithm by Greenwald et al. (2003). First, all latencies below $400 \mathrm{~ms}$ and above $10,000 \mathrm{~ms}$ were deleted. Afterwards, the practice scores on the incompatible trials were subtracted from the practice scores on the compatible trials. The same procedure was repeated for the test scores. In the last step, the test scores and practice scores were divided by their respective standard deviations. The mean of the two resulting scores functioned as the $D$-measure. Positive $D$-measure values indicated more negative implicit attitudes toward Turkish-origin students.

\section{Attributions}

We used an adapted version of the questionnaire developed by Froehlich et al. (2016), which considered three different dimensions of attributions for the lower educational success of ethnic minority students for which the term "ethnic minority students" was replaced by the term "students with Turkish roots." All dimensions used three items to assess the attributions. In the original version, lower employment rates were also targeted, but we decided to focus solely on the attributions for lower educational success. The first dimension 
captured internal stable attributions (e.g., "Turkish-origin students show lower academic performance compared with German students. This is because they have lower intellectual abilities"), Cronbach's $\alpha=.77$. The second dimension was the internal variable dimension (e.g., "This is because they do not study enough for school"), Cronbach's $\alpha=.81$. The final dimension was the external stable dimension (e.g., "This is because they suffer from disadvantages in the German educational system"), Cronbach's $\alpha=.73$.

Judgments of Students' Academic Competencies We compiled a questionnaire in the form of a semantic differential with the poles "German students" and "Turkish origin students." As academic competencies, we used orthography, grammar, and expression, which we merged into a variable called language proficiency (Cronbach's $\alpha=.90$.). The remaining items were mathematical and science ability as well as intelligence.

Demographic Questionnaire We compiled a questionnaire to assess participants' age and gender. We also asked whether the participants belonged to an ethnic minority themselves, and if so, we asked for their country of origin.

\section{Procedure}

The study was approved by the ethical committee of the University of Wuppertal. The participants were seated in front of the computer screen and first gave informed consent. All the measures were run on the computer. The first test was the IAT. The IAT began with a task for which they had to sort names into the categories "Turkish-origin students" or "German students" using the "E" and the "I" keys on the keyboard. Next, the same keys were used to sort pleasant and unpleasant words into these two categories. These were the first two phases. In the third phase, the two tasks were combined. For the compatible trials, participants used the same key to categorize pleasant words and German names, whereas the other key shared unpleasant and Turkish-origin names. For the incompatible trials, participants were asked to press the same key for words indicating pleasant words and Turkish-origin names and the remaining key to sort German names and unpleasant words. Half of the participants started the third phase with the compatible trials, and the other half with the incompatible trials. The participants underwent a practice and a test phase. In the fifth phase, the positions and keys of the pleasant and unpleasant categories were switched. Finally, the combinations of attribute words and target names appeared with this switched combination. Here, the participants worked in phase six on the practice and in phase seven on the test trials. The compatible and incompatible trials consisted of a practice phase with 40 trials and a test phase with 80 trials each. When the participants had finished the
IAT, they were asked to indicate how much they associated the competencies with either German or Turkish-origin students by using a scale ranging from 1 (German students) to 7 (Turkish-origin students). Afterwards, they were given the attribution questionnaire by Froehlich et al. (2016) to assess their agreement with the different statements on a 5-point Likert scale ranging from 1 (do not agree at all) to 5 (totally agree). Finally, they were given the demographic questionnaire before being thanked and debriefed.

\section{Results}

\section{Implicit Attitudes}

Preservice teachers' implicit attitudes were analyzed to figure out differences in their attitudes toward Turkish-origin versus German students. Therefore, the $D$-measure was submitted to an independent $t$ test, which indicated more negative implicit attitudes toward Turkish-origin students relative to German students $(M=0.33, S D=0.33), t(166)=12.97, p<.001, d=$ 1.00 .

\section{Attributions}

Accordingly, preservice teachers' attributions were examined regarding differences in their internal versus external attributions of Turkish-origin students' lower educational success compared to German students. We submitted the attributions to a dependent $t$ test, which showed that the preservice teachers endorsed the external attributions $(M=3.27, S D=$ $0.88)$ more than the internal ones $(M=1.95, S D=0.77)$, $t(165)=12.83, p<.001, d=1.00$. Hence, the participants attributed the failing educational success of ethnic minority students mainly to external causes.

\section{The Prediction of Judgments}

As a last step, correlational analyses and multiple regressions were calculated to analyze whether preservice teachers' implicit attitudes and internal and external attribution predicted their judgments of Turkish-origin students competencies. Correlational analyses showed substantial correlations between the judgments of intelligence and all other competency judgments (see Table 1).

Therefore, the more the preservice teachers associated intelligence with Turkish-origin students, the more the preservice teachers also associated good language proficiency and mathematical and science competencies with these students. When the preservice teachers perceived that Turkish-origin students possessed high mathematical competency, they also judged these students' science competency as high. Interestingly, the more the preservice teachers perceived 
Table 1 Correlations between Implicit Attitudes, Attributions, and Judgments

\begin{tabular}{llllllll}
\hline Variable & 1 & 2 & 3 & 4 & 5 & 6 & 7 \\
\hline 1 D-measure & 1 & -.11 & -.12 & -.10 & -.15 & $-.16^{*}$ & .08 \\
2 Internal attributions & & 1 &.$-28^{*}$ & $-.33^{*}$ & $-.17^{*}$ & $-.21^{*}$ & $-.49^{*}$ \\
3 External attributions & & & 1 & $.19^{*}$ & .11 & .07 & .08 \\
4 Language proficiency & & & 1 & .12 & .14 & $.24^{*}$ \\
5 Mathematical ability & & & & 1 & $.71^{*}$ & $.33^{*}$ \\
6 Science ability & & & & & 1 & $.44^{*}$ \\
7 Intelligence & & & & & & 1 \\
\hline
\end{tabular}

$* p<.05$

internal causes for the lower educational success of Turkish-origin students, the lower the association was between Turkish-origin students and academic competency. Preservice teachers who made stronger external attributions made weaker associations between Turkish-origin students and high language proficiency. Unsurprisingly, the more internal attributions the preservice teachers made, the fewer external attributions they made. The more negative the preservice teachers' implicit attitudes toward Turkish students were, the less strongly they associated the Turkish students with high science competency.

Finally, we computed four separate multiple regression analyses (see Table 2).

Table 2 Summary of the Multiple Regression Analyses with Implicit Attitudes, Internal Attributions, and External Attributions as Predictors and the Competency Judgments as Criteria

\begin{tabular}{lllll}
\hline Predictor & $B$ & $S E B$ & $\beta$ & $R^{2}$ \\
\hline Language proficiency & & & & .14 \\
$\quad$ D-measure & -0.31 & 0.19 & -.12 & \\
Internal attributions & $-0.34^{*}$ & 0.08 & $-.32^{*}$ & \\
External attributions & 0.09 & 0.07 & .09 & \\
Mathematical ability & & & & .07 \\
D-measure & $-0.29^{*}$ & 0.13 & $-.18^{*}$ & \\
Internal attributions & $-0.13^{*}$ & 0.06 & $-.18^{*}$ & \\
External attributions & 0.04 & 0.05 & .06 & \\
Science ability & & & & .08 \\
D-measure & $-0.33^{*}$ & 0.14 & $-.19^{*}$ & \\
Internal attributions & $-0.17^{*}$ & 0.06 & $-.23^{*}$ & \\
External attributions & -0.01 & 0.05 & -.02 & \\
Intelligence & & & & .25 \\
D-measure & 0.03 & 0.10 & .02 & \\
Internal attributions & $-0.32^{*}$ & 0.05 & $-.51^{*}$ & \\
External attributions & -0.04 & 0.04 & -.07 & \\
\hline
\end{tabular}

The language proficiency judgments were predicted by internal attributions. The more strongly the participants believed that the lower educational success of Turkish-origin students might be due to internal causes, the less strongly they associated high language proficiency with Turkish-origin students. No other variable predicted this judgment.

For the judgments of mathematical competency, both implicit attitudes and internal attributions were relevant. The more negative the implicit attitudes toward Turkish-origin students and the higher the internal attributions were, the less strongly the participants associated mathematical competency with Turkish-origin students. The same predictions were found for the judgments of science competency. Regarding the judgments of intelligence, participants with higher internal attributions did not associate intelligence with Turkish-origin students as strongly.

\section{Discussion}

Drawing on the two-stage model of dispositional attributions (Trope, 1986), we investigated how implicit attitudes such as identity information, internal attributions such as behavioral information, and external attributions such as situational information are related to judgments about the different academic competencies of ethnic minority students. We expected that more positive implicit attitudes toward ethnic minority students, higher internal attributions, and lower external attributions would result in judgments that associate greater competencies with ethnic minority students. The results only partially supported our hypotheses. Whereas the judgments of mathematical and science competency were predicted by participants' implicit attitudes as well as internal attributions, the judgment of the language proficiency was only predicted by internal attributions. Hence this study especially stresses the importance of (preservice) teachers' attributions of their students' achievements in identifying mechanisms that can contribute to disadvantages in school.

For the judgment of language proficiency, higher internal attributions predicted lower associations between language proficiency and ethnic minority students. This is in line with previous research that showed that not only did ethnic minority students perform lower on language proficiency (OECD, 2019), but they were judged as being less proficient by teachers and preservice teachers (Tobisch \& Dresel, 2017; Kleen \& Glock, 2018c). Our results imply that these lower judgments are partially due to the fact that ethnic minority students often do not speak the ethnic majority language in their homes (Strobel \& Kristen, 2015), which teachers suggest is negatively related to academic achievement (Agirdag et al., 2014a). Simultaneously, low effort and low willingness to speak the ethnic majority language are perceived as problematic (Agirdag et al., 2014b) and might, along with a preference 
for speaking one's native language at home, contribute to the relation between internal attributions and lower language proficiency.

In contrast to the language proficiency judgments, the judgments of mathematical and science competencies were both predicted by implicit attitudes and internal attributions. The more negative the implicit attitudes were and the higher the preservice teachers agreed with internal attributions, the lower the competency judgments were. Competence is, besides warmth, one of the main dimensions of stereotypes, (Fiske et al., 2002), and research has shown that Turkish-origin people are perceived as cold and incompetent (Asbrock, 2010). Such competence stereotypes are related to implicit attitudes (Krischler et al., 2018). Thus, our results might reflect this relationship, such that more negative implicit attitudes are related to lower competency ratings. Internal attributions predicted not only judgments of mathematical and science competencies but also judgments of intelligence. This is in line with previous research, which showed that internal attributions were related to judgments of lower academic competence (Froehlich et al., 2016), thus simply reflecting the ultimate attribution error (Pettigrew, 1979).

However, the finding that implicit attitudes showed no relation to intelligence judgments is somewhat surprising because mathematical competency can be found in the form of numerical reasoning in the conceptualization of intelligence (Süß \& Beauducel, 2015). Even science ability is related to logical reasoning (Piburn, 1990), and both mathematical and science competencies have been predicted by implicit attitudes. Interestingly, implicit attitudes also did not predict language proficiency judgments. The relation between language proficiency and implicit attitudes might have been detected if we had asked about language proficiency with respect to students' first language because this might be more strongly related to group membership than language proficiency in the ethnic majority language. To this effect, research has shown that speaking one's first language at home contributes to lower academic success (Mok et al., 2016) but that speaking the ethnic majority language does not increase academic success (Driessen et al., 2002). Moreover, speaking one's first language at school is perceived as particularly negative by teachers and influences teachers' attitudes toward ethnic minority students in a negative way (Agirdag et al., 2014a). This implies that implicit attitudes should be more visible in judgments of proficiency in the first language. However, this idea is quite speculative and should be explored more deeply in future research.

One reason for the missing relations could be grounded in how we assessed implicit attitudes. We used names as indicators of the two categories "German students" and "Turkish-origin students." In this regard, research has shown that ethnic minority names, in particular, names indicating a Turkish origin, are associated with lower intelligence ratings than names that indicate an ethnic majority background (Bonefeld \& Dickhäuser, 2018). Thus, these intelligence ratings, which might have been activated by the names, can be assumed to already be inherent in attitudes. Implicit attitudes are triggered automatically (Fazio, 2001) and have often been assessed by using names (Dovidio et al., 2001). Thus, we might assume that some parts of attitudes are influenced by stereotypical beliefs about the intelligence and possibly students' language proficiency related to the names. In turn, we might not be able to explain additional variance in judgments. Future research may be able to circumvent this issue by using photographs of students for which dimensions such as intelligence can be held constant (Glock et al., 2013), even though, when using photographs it has to be considered that those could also indicate the race of a student not only his or her ethnic belonging (Glock \& Böhmer, 2018). Another reason might be that preservice teachers might hold implicit theories of intelligence of different student groups, and sometimes, these theories are predictors of implicit attitudes (Enea-Drapeau et al., 2017), also resulting in the same collinearity described above. Future research should assess these implicit theories of intelligence, which can also be assessed with implicit methods (Mascret et al., 2015). Moreover, judgments have been shown to be influenced by the need for cognition of the judges (Haddock \& Maio, 2019). This seems to be another factor, which should be considered in future research.

Even though the preservice teachers generally made more external than internal attributions, their external attributions did not contribute to any judgment. Previous research has also shown stronger external than internal attributions (Froehlich et al., 2016). External attributions emphasize causes that are grounded in the school system (Froehlich et al., 2016), but in Germany, many programs to promote the ethnic majority language among ethnic minority students and their families have been developed (Becker-Mrotzek \& Roth, 2017) and might provide students with opportunities to overcome the deficits they show in language proficiency (Ehmke et al., 2013). Hence, lower proficiency levels cannot easily be attributed to external factors.

What is more, people are often reluctant to make internal attributions because they do not want to discriminate against or contribute to the disadvantages of some groups (Crosby, 1984). External attributions, however, were endorsed usually to explain the success of, for instance, students with learning disabilities (Vlachou et al., 2014) but not to explain students' failures (Conway, 1989). The missing predictive power of external attributions for judgments reflects not only the fundamental (Ross, 1977) but also the ultimate attribution error (Pettigrew, 1979). In our study, the external causes were all related to the school system, which might not properly reflect the situational cues specified in the two-stage model (Trope, 1986). Such situational cues can also be related to students' parents and home environments. These are external causes, 
and research has shown that, for instance, teachers tend to attribute student misbehavior to the parents and the home environment (Mavropoulou \& Padeliadu, 2002). We also know that family background can predict students' academic achievement and so can teachers' school track recommendations (Caro et al., 2009). Hence, the reliance on school-related factors in external attributions might be the reason for the null effects. It would therefore be valuable to add some more external causes as situational cues.

\section{Limitations}

Besides these ideas for future research, our study is limited in more aspects. First and foremost, our study was not a field study but was conducted on computers in a laboratory setting. However, this allowed us to systematically manipulate and control confounding variables, but it also limited the ecological validity of our results. This controversy between experimental control and ecological validity has been a topic of discussion since Brunswik (1955) first introduced ecological validity. There is no easy solution to this conflict. Some researchers claim that the most important issue is not the question of whether the laboratory setting resembles a real-life situation (mundane realism; Berkowitz \& Donnerstein, 1982) but instead involves psychological realism, which is defined as the degree to which the psychological processes that occur in the laboratory setting mirror those that occur in real life (Aronson et al., 1998). However, even though teachers in school have more information about their students and many opportunities to develop attitudes toward these students, it is these situations with high cognitive demands that result in automatic processing (Olson \& Fazio, 2009b), making the influence of implicit attitudes more likely (Olson \& Fazio, 2009b; De Houwer et al., 2009). In school, teachers have to manage many tasks under high constraints (Santavirta et al., 2007), which may pave the way for implicit attitudes (Glock et al., 2013).

Another limiting factor is that we assessed implicit attitudes only toward male students. Although research has shown that there seems to be no differences between implicit attitudes toward male and female ethnic minority students - as both were more negative compared with ethnic majority students (Kleen \& Glock, 2018b) - it might make a difference because, in the remaining measures, we did not differentiate between students' gender. Even if there were no differences in implicit attitudes, teachers' perceptions (Kulinna, 2008) may mirror male students' behavioral adjustment difficulties (Alexander et al., 1997) and their lower achievement in language proficiency when compared with female students (Driessen \& van Langen, 2013).

As we used names in our study, we did not ensure that the participants did not share the same name or that their names did not share some letters with those presented. From previous research we know, that people show implicit preferences for letters which are contained in their name (Nuttin, 1985). This might have had contributed to the results. Hence, in future research, we might have a profound basis of names, which can be randomly chosen according to the names of the participants.

We also did not consider the preservice teachers' own ethnic background as a predictor of implicit attitudes and causal attributions. Although some participants had an ethnic minority background themselves, only a very small number had a Turkish background. To this extent, research has shown that it is important that preservice teachers share the same ethnic background as their students for determining implicit attitudes (Kleen et al., 2019), causal attributions, and judgments of ethnic minority students (Glock \& Schuchart, 2020). The number of preservice teachers with an ethnic minority background will increase in the future (Kleen et al., 2019) and will thus become an important group not only for research but also for the benefit of ethnic minority students. Students will benefit not only from more favorable attitudes and judgments but also from these teachers' profound knowledge about the problems these students face (Villegas \& Irvine, 2010) as ethnic minority teachers are more likely to have had similar experiences (OECD, 2018). However, results also showed that the ethnic minority preservice teachers were more negative toward ethnic majority compared to ethnic minority students (Keen et al., 2019), which could therefore also possibly lead to biased judgments. Hence, it might proof beneficial to find ways to change (preservice) teachers' implicit and explicit attitudes. According to the Elaboration Likelihood Model (Petty \& Cacioppo, 1986), automatic as well as controlled routes can lead to changes in attitudes. Programs that are especially designed to address the change of attitudes could be useful in this scenario.

\section{Conclusion}

Drawing on the two-stage model of dispositional attributions (Trope, 1986), we linked implicit attitudes and causal attributions to competency judgments in the educational domain. We focused on ethnic minority students as one group that is faced with lower teachers' expectations in many school systems around the world (van den Bergh et al., 2010). Previous research has already shown that attitudes are related to lower expectations and varying teacher behavior (van den Bergh et al., 2010) as well as to lower judgments (Glock \& Böhmer, 2018), and our study adds the important factor of attributions to this approach. In the school context, how students make attributions for the causes of their successes and failures is important, but it seems to be even more pivotal how teachers make these attributions. Teachers often base their 
feedback on their attributions, and their feedback is more negative when internal attributions are made (Medway, 1979). Along with the effect of implicit attitudes, this means not only that ethnic minority students will be judged as having lower competencies but also that teachers will be more critical in their feedback. Thus, along with internal attributions, this can influence students' motivation in a negative way (Licht \& Kistner, 1986), which might also contribute to lower academic achievement (Wentzel et al., 1990). However, as this is the first study to relate implicit attitudes and attributions to judgments, it can be seen as a first step toward shedding further light on the role that teachers - more specifically future teachers - play in contributing to the disadvantages that ethnic minority students experience in school.

Acknowledgements We also would like to thank Meike Bonefeld for her assistance in compiling the items of the semantic differential beliefs scale.

Funding Open Access funding enabled and organized by Projekt DEAL.

Data Availability The datasets generated during and/or analysed during the current study are available from the corresponding author on reasonable request.

\section{Declarations}

Conflict of Interest The authors have no competing interests.

Open Access This article is licensed under a Creative Commons Attribution 4.0 International License, which permits use, sharing, adaptation, distribution and reproduction in any medium or format, as long as you give appropriate credit to the original author(s) and the source, provide a link to the Creative Commons licence, and indicate if changes were made. The images or other third party material in this article are included in the article's Creative Commons licence, unless indicated otherwise in a credit line to the material. If material is not included in the article's Creative Commons licence and your intended use is not permitted by statutory regulation or exceeds the permitted use, you will need to obtain permission directly from the copyright holder. To view a copy of this licence, visit http://creativecommons.org/licenses/by/4.0/.

\section{References}

Agirdag, O., Jordens, K., \& Van Houtte, M. (2014a). Speaking Turkish in Belgian primary schools: Teacher beliefs versus effective consequences. Bilig, 70, 7-28. https://doi.org/10.12995/bilig.2014.7001.

Agirdag, O., Merry, M. S., \& Van Houtte, M. (2014b). Teachers' understanding of multicultural education and the correlates of multicultural content integration in Flanders. Education and Urban Society, 48(6), 556-582. https://doi.org/10.1177/0013124514536610

Alexander, K. L., Entwisle, D. R., \& Horsey, C. S. (1997). From first grade forward: Early foundations of high school dropout. Sociology of Education, 70(2), 87-107. https://doi.org/10.2307/2673158.

Aronson, E., Wilson, T. D., \& Brewer, M. B. (1998). Experimentation in social psychology. In D. T. Gilbert, S. T. Fiske, \& G. Lindzey
(Eds.), The handbook of social psychology, Vols. 1 and 2 (4th ed., pp. 99-142). McGraw-Hill

Asbrock, F. (2010). Stereotypes of social groups in Germany in terms of warmth and competence. Social Psychology, 41, 76-81. https://doi. org/10.1027/1864-9335/a000011.

Becker-Mrotzek, M., \& Roth, H.-J. (2017). Vorwort [Foreword]. In M. Becker-Mrotzek \& H.-J. Roth (Eds.), Sprachliche Bildung: Grundlagen und Handlungsfelder (pp. 7-9). Waxmann.

Berkowitz, L., \& Donnerstein, E. (1982). External validity is more than skin deep: Some answers to criticisms of laboratory experiments. American Psychologist, 37, 245-257. https://doi.org/10.1037/0003066X.37.3.245.

Bonefeld, M., \& Dickhäuser, O. (2018). (biased) grading of students' performance: Students' names, performance level, and implicit attitudes. Frontiers in Psychology, 9, 481. https://doi.org/10.3389/ fpsyg.2018.00481.

Brunswik, E. (1955). Representative design and probabilistic theory in a functional psychology. Psychological Review, 62, 193-217. https:// doi.org/10.1037/h0047470.

Caro, D., Lenkeit, R., Lehmann, R., \& Schwippert, K. (2009). The role of academic achievement growth in school track recommendations. Studies in Educational Evaluation, 35, 183-192. https://doi.org/10. 1016/j.stueduc.2009.12.002.

Conway, A. (1989). Teachers' explanations for children with learning difficulties: An analysis of written reports. Early Child Development and Care, 53, 53-61. https://doi.org/10.1080/ 0300443890530107.

Crosby, F. (1984). The denial of personal discrimination. American Behavioral Scientist, 27, 371-386. https://doi.org/10.1177/ 000276484027003008.

Cuddy, A. J. C., Fiske, S. T., \& Glick, P. (2008). Warmth and competence as universal dimensions of social perception: The stereotype content model and the BIAS map. In M. P. Zanna (Ed.), Advances in Experimental Social Psychology (Vol. 40, pp. 61-149). Elsevier Academic Press. https://doi.org/10.1016/S0065-2601(07)00002-0.

De Houwer, J., Teige-Mocigemba, S., Spruyt, A., \& Moors, A. (2009). Implicit measures: A normative analysis and review. Psychological Bulletin, 135, 347-368. https://doi.org/10.1037/a0014211.

Denessen, E., Hornstra, L., van den Bergh, L., \& Bijlstra, G. (2021). Implicit measures of teachers ' attitudes and stereotypes, and their effects on teacher practice and student outcomes : A review. Learning and Instruction. https://doi.org/10.1016/j.learninstruc. 2020.101437

Destatis. (2017). Ausländische Bevölkerung [Foreign population]. https://www.destatis.de/DE/Themen/Gesellschaft-Umwelt/ Bevoelkerung/Migration-Integration/_inhalt.html?_blob= publicationFile

Dovidio, J. F., Kawakami, K., \& Beach, K. R. (2001). Implicit and explicit attitudes: Examination of the relationship between measures of intergroup bias. In R. Brown \& S. L. Gaertner (Eds.), Blackwell handbook of social psychology: Intergroup processes (pp. 175197). Blackwell Publishers.

Driessen, G., de Bot, K., \& van der Slik, F. W. P. (2002). Home language and language proficiency: A large-scale longitudinal study in Dutch primary schools. Journal of Multilingual and Multicultural Development, 23, 175-194. https://doi.org/10.1080/ 01434630208666464.

Driessen, G., \& van Langen, A. (2013). Gender differences in primary and secondary education: Are girls really outperforming boys? International Review of Education, 59(1), 67-86. https://doi.org/ 10.1007/s11159-013-9352-6.

Eagly, A. H., \& Chaiken, S. (1993). The psychology of attitudes. Harcourt Brace Jovanovich.

Ehmke, T., Klieme, E., \& Stanat, P. (2013). Veränderungen der Lesekompetenz von PISA 2000 nach PISA 2009. Die Rolle von Unterschieden in den Bildungswegen und in der 
Zusammensetzung der Schülerschaft [Changes in reading profiency from PISA 2000 to PISA 2009: The role off differences in educational . Zeitschrift für Pädagogik, 59(Beiheft), 132-150. https://doi. org/10.25656/01:7824

Enea-Drapeau, C., Carlier, M., \& Huguet, P. (2017). Implicit theories concerning the intelligence of individuals with down syndrome. PLoS One, 12(11), 1-12. https://doi.org/10.1371/journal.pone.0188513.

Fazio, R. H. (2001). On the automatic activation of associated evaluations: An overview. Cognition and Emotion, 15, 115-141. https:// doi.org/10.1080/0269993004200024.

Fishbein, M. (2008). An investigation of the relationship between the beliefs about an object and the attitude toward the object. In R. H. Fazio \& R. E. Petty (Eds.), Attitudes: Their structure, function, and consequences (pp. 133-136). Psychology Press.

Fiske, S. T., Cuddy, A. J. C., Glick, P., \& Xu, J. (2002). A model of (often mixed) stereotype content: Competence and warmth respectively follow from perceived status and competition. Journal of Personality and Social Psychology, 82(6), 878-902. https://doi. org/10.1037/0022-3514.82.6.878

Froehlich, L., Martiny, S. E., Deaux, K., \& Mok, S. Y. (2016). "It's their responsibility, not ours". Stereotypes about compentence and causal attributions for immigrants' academic underperformance. Social Psychology, 47, 74-86. https://doi.org/10.1027/1864-9335/a000260.

Gawronski, B., \& Bodenhausen, G. V. (2006). Associative and propositional processes in evaluation: An integrative review of implicit and explicit attitude change. Psychological Bulletin, 132, 692-731. https://doi.org/10.1037/0033-2909.132.5.692.

Gawronski, B., \& Creighton, L. A. (2013). Dual process theories. In D. E. Carlston (Ed.), The Oxford handbook of social cognition (pp. 282312). Oxford University Press.

Glock, S. (2016). Does ethnicity matter? The impact of stereotypical expectations on in-service teachers' judgments of students. Social Psychology of Education, 19(3), 493-509. https://doi.org/10.1007/ s11218-016-9349-7

Glock, S., \& Böhmer, I. (2018). Teachers' and preservice teachers' stereotypes, attitudes, and spontaneous judgments of male ethnic minority students. Studies in Educational Evaluation, 59, 244-255. https://doi.org/10.1016/j.stueduc.2018.09.001

Glock, S., \& Karbach, J. (2015). Preservice teachers' implicit attitudes toward racial minority students: Evidence from three implicit measures. Studies in Educational Evaluation, 45, 55-61. https://doi.org/ 10.1016/j.stueduc.2015.03.006

Glock, S., \& Kleen, H. (2017). Gender and student misbehavior: Evidence from implicit and explicit measures. Teaching and Teacher Education, 67, 93-103. https://doi.org/10.1016/j.tate. 2017.05.015

Glock, S., \& Schuchart, C. (2020). The ethnic match between students and teachers: Evidence from a vignette study. Social Psychology of Education, 23(1), 27-50. https://doi.org/10.1007/s11218-01909525-2

Glock, S., Kneer, J., \& Kovacs, C. (2013). Preservice teachers' implicit attitudes toward students with and without immigration background: A pilot study. Studies in Educational Evaluation, 39, 204-210. https://doi.org/10.1016/j.stueduc.2013.09.003

Gonsalkorale, K., Allen, T. J., Sherman, J. W., \& Klauer, K. C. (2010). Mechanisms of group membership and exemplar exposure effects on implicit attitudes. Social Psychology, 41, 158-168. https://doi. org/10.1027/1864-9335/a000023.

Greenwald, A. G., McGhee, D. E., \& Schwartz, J. K. L. (1998). Measuring individual differences in implicit cognition: The implicit association test. Journal of Personality and Social Psychology, 74, 1464-1480. https://doi.org/10.1037/0022-3514.74.6.1464.

Greenwald, A. G., Nosek, B. A., \& Banaji, M. R. (2003). Understanding and using the implicit association test I: An improved scoring algorithm. Journal of Personality and Social Psychology, 85, 197-216. https://doi.org/10.1037/0022-3514.85.2.197.
Haddock, G., \& Maio, G. R. (2019). Inter-individual differences in attitude content: Cognition, affect, and attitudes. In Advances in Experimental Social Psychology (1st ed., Vol. 59). Elsevier Inc. https://doi.org/10.1016/bs.aesp.2018.10.002.

Hamilton, D. L., \& Sherman, S. J. (1996). Perceiving persons and groups. Psychological Review, 103, 336-355. https://doi.org/10.1037/0033295X.103.2.336

Hewstone, M. (1990). The "ultimate attribution error"? A review of the literature on intergroup causal attribution. European Journal of Social Psychology, 20, 311-335. https://doi.org/10.1002/ejsp.2420200404|.

Heyder, A., Kessels, U., \& Steinmayr, R. (2017). Explaining academictrack boys' underachievement in language grades: Not a lack of aptitude but students ' motivational beliefs and parents' perceptions? British Journal of Educational Psychology, 87, 205-223. https:// doi.org/10.1111/bjep.12145.

Jackson, S. A. (2002). A study of teachers' perceptions of youth problems. Journal of Youth Studies, 5, 313-323. https://doi.org/10.1080/ 1367626022000005992.

Jordan, W. J. (2010). Defining equity: Multiple perspectives to analyzing the performance of diverse learners. Review of Research in Education, 34, 142-178. https://doi.org/10.3102/0091732X09352898.

Kleen, H., \& Glock, S. (2018a). A further look into ethnicity: The impact of stereotypical expectations on teachers' judgments of female ethnic minority students. Social Psychology of Education, 21(4), 759773. https://doi.org/10.1007/s11218-018-9451-0

Kleen, H., \& Glock, S. (2018b). Good classroom management for ethnic minority students? A comparison of the strategies that preservice and inservice teachers use to respond to student misbehavior. Journal of Classroom Interaction, 53(2), 4-20

Kleen, H., \& Glock, S. (2018c). The roles of teacher and student gender in German teachers' attitudes toward ethnic minority students. Studies in Educational Evaluation, 59, 102-111. https://doi.org/10.1016/j. stueduc.2018.04.002.

Kleen, H., Bonefeld, M., Glock, S., \& Dickhäuser, O. (2019). Implicit and explicit attitudes toward Turkish students in Germany as a function of teachers' ethnicity. Social Psychology of Education, 22, 883899. https://doi.org/10.1007/s11218-019-09525-2.

Krischler, M., Pit-ten Cate, I. M., \& Krolak-Schwerdt, S. (2018). Mixed stereotype content and attitudes toward students with special educational needs and their inclusion in regular schools in Luxembourg. Research in Developmental Disabilities, 75, 59-67. https://doi.org/ 10.1016/j.ridd.2018.02.007

Kristen, C. (2000). Ethnic differences in educational placement: The transition from primary to secondary schooling (working papers 32; Arbeitspapiere, issue 16.07.2009).

Kulinna, P. H. (2008). Teachers' attributions and strategies for student misbehavior. Journal of Classroom Interaction, 42, 21-30.

Lambert, A. J., Payne, B. K., Ramsey, S., \& Shaffer, L. M. (2005). On the predictive validity of implicit attitude measures: The moderating effect of perceived group variability. Journal of Experimental Social Psychology, 41, 114-128. https://doi.org/10.1016/j.jesp.2004.06.006.

Licht, B. G., \& Kistner, J. A. (1986). Motivational problems of learningdisabled children: Individual differences and their implications for treatment. In J. K. Torgesen \& B. Y. L. Wong (Eds.), Psychological and educational perspectives on learning disabilities (pp. 225-255). Academic Press.

Mascret, N., Roussel, P., \& Cury, F. (2015). Using implicit measures to highlight science teachers' implicit theories of intelligence. European Journal of Psychology of Education, 30, 269-280. https://doi.org/10.1007/s10212-015-0249-6.

Mavropoulou, S., \& Padeliadu, S. (2002). Teachers' causal attributions for behaviour problems in relation to perceptions of control. Educational Psychology, 22(2), 191-202. https://doi.org/10.1080/ 01443410120115256 
Medway, F. J. (1979). Causal attributions for school-related problems: Teacher perceptions and teacher feedback. Journal of Educational Psychology, 71, 809-818. https://doi.org/10.1037/0022-0663.71.6.809.

Mok, S. Y., Martiny, S. E., Gleibs, I. H., Keller, M. M., \& Froehlich, L. (2016). The relationship between ethnic classroom composition and Turkish-origin and German students' reading performance and sense of belonging. Frontiers in Psychology, 7, 1-12. https://doi. org/10.3389/fpsyg.2016.01071.

Natale, K., Viljaranta, J., Lerkkanen, M. K., Poikkeus, A. M., \& Nurmi, J. E. (2009). Cross-lagged associations between kindergarten teachers' causal attributions and children's task motivation and performance in reading. Educational Psychology, 29, 603-619. https://doi.org/ 10.1080/01443410903165912.

Nosek, B. A., Greenwald, A. G., \& Banaji, M. R. (2005). Understanding and using the implicit association test: II. Method variables and construct validity. Personality \& Social Psychology Bulletin, 31(2), 166-180. https://doi.org/10.1177/0146167204271418.

Nuttin, J. M. (1985). Narcissism beyond gestalt and awareness: The name letter effect. European Journal of Social Psychology, 15, 353-361. https://doi.org/10.1002/ejsp.2420150309.

OECD (Ed.). (2018). Catching up? Country studies on intergenerational mobility and children of immigrants. OECD.

OECD. (2019). PISA 2018 results. Where all students can succeed: Vol. II. OECD Publishing.

Olson, M. A., \& Fazio, R. H. (2009a). Implicit and explicit measures of attitudes: The perspective of the MODE model. In R. E. Petty, R. H. Fazio, \& P. Briñol (Eds.), Attitudes: Insights from the new implicit measures (pp. 19-63). Psychology Press.

Olson, M. A., \& Fazio, R. H. (2009b). The perspective of the MODE model. In P. Petty, R. E. Fazio, \& R. H. Brinol (Eds.), Attitudes: Insights form the new implicit measures (pp. 19-63). Psychology Press.

Peterson, E. R., Rubie-Davies, C. M., Osborne, D., \& Sibley, C. (2016). Teachers' explicit expectations and implicit prejudiced attitudes to educational achievement: Relations with student achievement and the ethnic achievement gap. Learning and Instruction, 42, 123-140. https://doi.org/10.1016/j.learninstruc.2016.01.010.

Pettigrew, T. F. (1979). The ultimate attribution error: Extending Allport's cognitive analysis of prejudice. Personality and Social Psychology Bulletin, 5, 461-476. https://doi.org/10.1177/ 014616727900500407.

Petty, R. E., \& Cacioppo, J. T. (1986). The elaboration likelihood model of persuasion. In L. Berkowitz (Ed.), Advances in experimental social psychology (pp. 123-205). Academic Press.

Piburn, M. D. (1990). Reasoning about logical propositions and success in science. Journal of Research in Science Teaching, 27, 887-900. https://doi.org/10.1002/tea.3660270908.

Pit-ten Cate, I. M., \& Glock, S. (2019). Teachers ' implicit attitudes toward students from different social groups: A meta-analysis. Frontiers in Psychology, 10, 2832. https://doi.org/10.3389/fpsyg. 2019.02832

Riley, T., \& Ungerleider, C. (2012). Self-fulfilling prophecy: How teachers' attributions, expectations, and stereotypes influence the learning opportunities afforded by aboriginal students. Canadian Journal of Education, 35, 303-333.

Ross, L. (1977). The intuitive psychologist and his shortcomings: Distortions in the attribution process. Advances in Experimental Social Psychology, 10, 173-220. https://doi.org/10.1016/S00652601(08)60357-3.

Santavirta, N., Solovieva, S., \& Theorell, T. (2007). The association between job strain and emotional exhaustion in a cohort of 1.028 Finnish teachers. British Journal of Educational Psychology, 77(1), 213-228. https://doi.org/10.1348/000709905X92045.

Smith, E. R. (1998). Mental representation and memory. In D. T. Gilbert, S. T. Fiske, \& G. Lindzey (Eds.), Handbook of social cognition ( $p p$. 391-445). McGraw-Hill.
Strobel, B., \& Kristen, C. (2015). Erhalt der Herkunftssprache? - Muster des Sprachgebrauchs in Migrantenfamilien [Language maintenance? Patterns of language use in immigrant families]. Zeitschrift für Erziehungswissenschaft, 18, 125-142. https://doi.org/10.1007/ s11618-014-0607-1.

Süß, H.-M., \& Beauducel, A. (2015). Modeling the construct validity of the Berlin intelligence structure model. Estudos de Psicologia (Campinas), 32, 13-25. https://doi.org/10.1590/0103$166 \times 2015000100002$.

Teachman, B. A., Gapinski, K. D., Brownell, K. D., Rawlins, M., \& Jeyaram, S. (2003). Demonstrations of implicit anti-fat bias: The impact of providing causal information and evoking empathy. Health Psychology, 22, 68-78. https://doi.org/10.1037/0278-6133.22.1.68.

Tobisch, A., \& Dresel, M. (2017). Negatively or positively biased? Dependencies of teachers' judgments and expectations based on students' ethnic and social backgrounds. Social Psychology of Education, 20, 731-752. https://doi.org/10.1007/s11218-017-9392-z.

Tom, D., \& Cooper, H. (1986). The effect of student background on teacher performance attributions: Evidence for counterdefensive patterns and low expectancy cycles. Basic and Applied Social Psychology, 7, 53-62. https://doi.org/10.1207/s15324834basp0701.

Trope, Y. (1986). Identification and inferential processes in dispositional attribution. Psychological Review, 93, 239-257. https://doi.org/10. 1037/0033-295X.93.3.239.

Trope, Y. (2004). Theory in social psychology: Seeing the forest and the trees. Personality and Social Psychology Review, 8, 193-200. https://doi.org/10.1207/s15327957pspr0802_13.

Trope, Y., \& Gaunt, R. (1999). A dual process model of overconfident attributional inferences. In S. Chaiken \& Y. Trope (Eds.), Dual process theories in social psychology (pp. 161-178). The Guilford Press.

Tur-Kaspa, H., \& Weisel, A. (2004). Teachers' causal attributions for low-achieving students' academic performance: The effcts of labels and contact. Thalamus, 22(1), 33-39.

Uleman, J. S., Newman, L. S., \& Moskowitz, G. B. (1996). People as flexible interpreters: Evidence and issues from spontaneous trait inferences. Advances in Experimental Social Psychology, 28, 211279. https://doi.org/10.1016/S0065-2601(08)60239-7.

van den Bergh, L., Denessen, E., Hornstra, L., Voeten, M., \& Holland, R. W. (2010). The implicit prejudiced attitudes of teachers: Relations to teacher expectations and the ethnic achievement gap. American Educational Research Journal, 47, 497-527. https://doi.org/10. 3102/0002831209353594.

Villegas, A. M., \& Irvine, J. J. (2010). Diversifying the teaching force: An examination of major arguments. Urban Review, 42, 175-192. https://doi.org/10.1007/s11256-010-0150-1.

Vlachou, A., Eleftheriadou, D., \& Metallidou, P. (2014). Do learning difficulties differentiate elementary teachers' attributional patterns for students' academic failure? A comparison between Greek regular and special education teachers. European Journal of Special Needs Education, 29, 1-15. https://doi.org/10.1080/08856257.2013.830440.

Wang, H., \& Hall, N. C. (2018). A systematic review of teachers' causal attributions: Prevalence, correlates, and consequences. Frontiers in Psychology, 9(2305), 1-22. https://doi.org/10.3389/fpsyg.2018.02305.

Weiner, B. (1985). An attributional theory of achievement motivation and emotion. Psychological Review, 92, 548-573. https://doi.org/10. 1037/0033-295X.92.4.548.

Weiner, B. (2000). Intrapersonal and interpersonal theories of motivation from an attributional perspective. Educational Psychology Review, 12(1), 1-14. https://doi.org/10.1023/A:1009017532121.

Wentzel, K. R., Weinberger, D. A., Ford, M. E., \& Feldman, S. S. (1990). Academic achievement in preadolescence: The role of motivational, affective, and self-regulatory processes. Journal of Applied Developmental Psychology, 11, 179-193. https://doi.org/10.1016/ 0193-3973(90)90004-4. 
Wiley, M. G., \& Eskilson, A. (1978). Why did you learn in school today? Teachers' perceptions of causality. Sociology of Education, 51, 261-269.

Wissink, I. B., \& de Haan, M. (2013). Teachers' and parental attribution for school performance of ethnic majority and minority children. International Journal of Higher Education, 2(4), 65-76. https:// doi.org/10.5430/ijhe.v2n4p65.
Yehuda, Y. B. (2002). Self-serving attributions in teachers' explanations of students' performance in a national oral essay competition. Social Behavior and Personality: An International Journal, 30, 411-415. https://doi.org/10.2224/sbp.2002.30.4.411.

Publisher's Note Springer Nature remains neutral with regard to jurisdictional claims in published maps and institutional affiliations. 